\title{
Pemberdayaan Ekonomi Keluarga Melalui Unit Produksi Pengolahan Makanan Pada Kelompok Dasawisma RW. oz Nasri Moyudan
}

\author{
Harjanti Widiastuti', Evy Rahman Utami² \\ 1,2Program Studi Akuntansi Fakultas Ekonomi dan Bisnis Universitas Muhammadiyah Yogyakarta \\ Email: widyas@umy.ac.id \\ DOI: $10.18196 / p p m \cdot 34.282$
}

\begin{abstract}
ABSTRAK
Mitra yang terlibat dalam kegiatan pengabdian ini adalah kelompok dasa wisma RW o7 di pedukuhan Nasri Sumbersari Moyudan Sleman Yogyakarta. Permasalahan yang dihadapi mitra yaitu perempuan usia produktif dan berkeluarga yang tidak mempunyai ketrampilan dan pekerjaan, sementara suami-suami mereka rata-rata bekerja di sektor informal. Pandemi sangat berdampak pada kondisi perekonomian mitra, sehingga membuat usaha makanan rumahan merupakan pilihan mereka untuk dapat menyokong ekonomi keluarga. Program pengabdian ini dilaksanakan dengan pembentukan kelompok usaha, pelatihan pengolahan makanan, perhitungan harga pokok dan manajemen keuangan, pengemasan, dan pemasaran secara online. Kegiatan ini memberikan solusi terhadap permasalahan mitra dengan terbentuknya beberapa kelompok usaha dan peningkatan keterampilan masyarakat sehingga kelompok dasa wisma mampu memberdayakan diri untuk memulai berwirausaha, mendukung ekonomi keluarga, dan diharapkan mampu menciptakan masyarakat yang mandiri secara ekonomi.
\end{abstract}

Kata Kunci: Kewirausahaan, Pengolahan Makanan, Dasa Wisma, Kemandirian Ekonomi

\section{PENDAHULUAN}

Mitra dalam kegiatan pengabdian masyarakat ini adalah kelompok dasa wisma di RW 07 Jetis Sumbersari Moyudan Sleman. Jumlah penduduk di Jetis RW 07 Sumbersari sebagian besar $(68 \%)$ perempuan dan tidak memiliki perkerjaan atau ibu rumah tangga. Berdasarkan observasi dan diskusi antara tim pengabdian dan mitra menunjukkan rata-rata masyarakat memiliki minat dan bakat pengolahan makanan. Untuk itu perlu ada pelatihan dan pendampingan untuk pengolahan makanan yang layak jual sehingga dapat mendukung ekonomi keluarga. Kondisi tersebut menjadi perhatian kegiatan pengabdian ini untuk membantu masyarakat dengan program-program yang dapat meningkatkan kemandirian ekonomi.

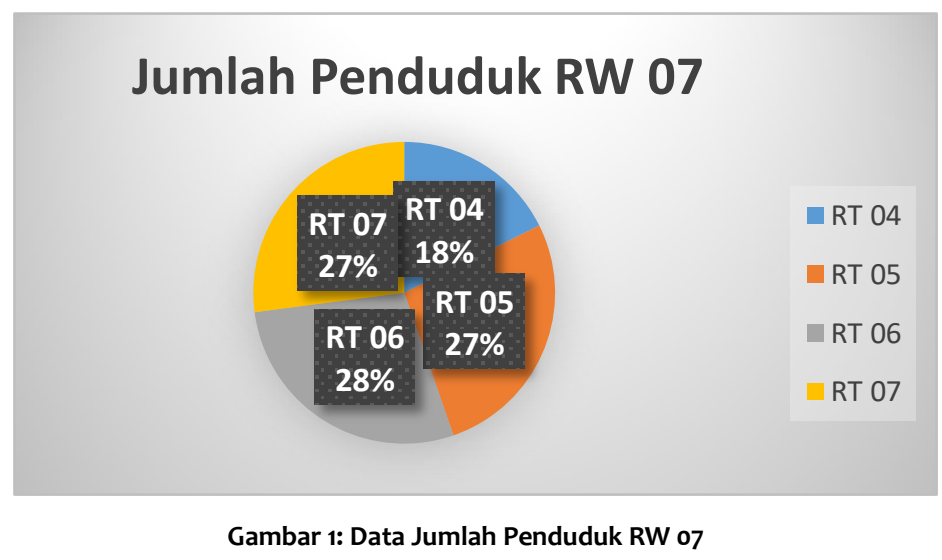

Kemandirian ekonomi merupakan faktor penting yang harus dipikirkan oleh berbagai pihak. Kemandirian adalah satu sikap yang mengutamakan kemampuan diri sendiri dalam mengatasi berbagai masalah demi mencapai satu tujuan, tanpa menutup diri terhadap berbagai 
kemungkinan kerjasama yang saling menguntungkan (Mukeri 2012). Program kemandirian ekonomi difokuskan pada usia produktif dan sudah berkerluarga. Hal ini didasarkan pada kondisi demografi mitra dimana jumlah perempuan usia produktif adalah jumlah terbesar. Dengan demikian dibutuhkan sebuh program yang dapat membuka lapangan pekerjaan untuk memberdayakan masyarakat terutama kaum perempuan dengan berbasis potensi lokal (Saugi and Sumarno 2015). Selain itu, sejak Maret 2020 Covid-19 menyerang masyarakat Indonesia sehingga berdampak pada berbagai sektor kehidupan, khususnya perekononomian masyarakat. Untuk itu, perempuan mempunyai peran yang semakin penting untuk membantu perekonomian keluarga karena berkurangnya lapangan pekerjaan, banyak karyawan di PHK atau dirumahkan, dan kegiatan ekonomi tidak berjalan dengan baik.

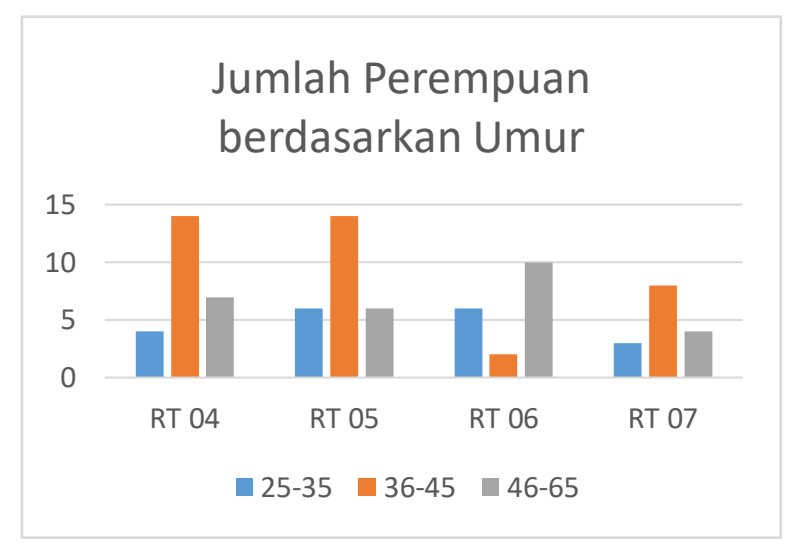

Gambar 2 : Data Jumlah Perempuan berdasarkan Umur
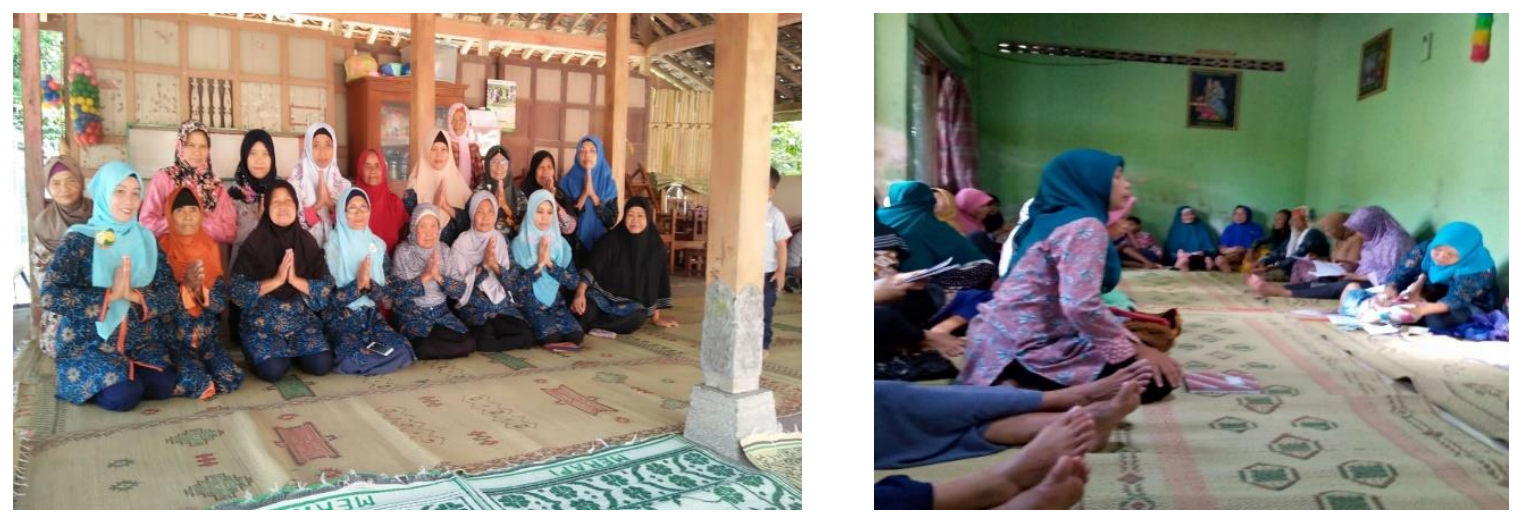

Gambar 3 dan 4: Pengurus Dasa Wisma RW 07 \& Kegiatan Rutin

Berdasarkan hasil observasi yang disampaikan dalam analisis situasi mitra, dapat diidentifikasi bahwa kelompok dasa wisma ini memiliki berbagai permasalahan. Pertama, kurangnya pemberdayaan ibu-ibu rumah tangga dalam kelompok dasa wisma usia produktif dalam rangka menghasilkan sumber pendukung ekonomi keluarga. Beberapa ibu sudah membuat makanan untuk dititipkan namun dengan ketrampilan yang terbatas. Kedua, mitra tidak memiliki ketrampilan pengolahan makanan, pengemasan, dan pemasaran yang baik. Ketiga, tiap rumah tangga rata-rata memiliki hasil kebun (pisang, singkong, ubi jalar) dan hasil ternak (ayam, bebek) yang dijual begitu saja tanpa pengolahan, padahal sebenarnya memiliki keluangan waktu. Dampak pandemik sangat terasa bagi ibu-ibu RW 07 karena sebagian besar suami mereka bekerja di sector informal (tukang, buruh, karyawan toko) yang penghasilan turun karena tidak ada pekerjaan atau bekerja tidak penuh seperti sebelum pandemic. Berdasarkan observasi dan diskusi dengan ibu Dukuh ditemukan beberapa potensi yang dimiliki di 
lingkungan Nasri untuk dapat dikembangkan dalam upaya meningkatkan kemandirian ekonomi keluarga. Program yang disepakati untuk diangkat adalah program peningkatan keterampilan berwirausaha pengolahan makanan. Pilihan ini dirasa paling memungkinkan untuk dilaksanakan dan berkelanjutan karena pada dasarnya ibu-ibu memiliki kemampuan memasak, dan keluangan waktu untuk memproduksi makanan hanya belum memiliki pengetahuan dan keterampilan menjalankan usaha. Program ini didesain untuk meningkatkan keterampilann berwirausaha pengolahan makan kegiatan, seperti Pelatihan motivasi kewirausahaan dan manajemen keuangan untuk kelompok dasa wisma RT 07, pelatihan dan pendampingan ketrampilan pengolahan makanan. Mitra membantu berbagai peralatan untuk mendukung kelancaran dan keberlanjutan program, begitu pula pelatihan pengemasan dan pendampingan pemasaran secara online.

\section{METODE}

Target kegiatan ini adalah anggota kelompok dasa wisma di Nasri Sumbersari Moyudan Sleman. Pemberdayaan masyarakat dilakukan dengan berbagai kegiatan sebagai berikut:

A. Tim pengabdian melakukan sosialisasi, observasi, dan diskusi dengan kepala dusun dan pengurus dasawisma. Kegiatan ini dilakukan untuk mengumpulkan berbagai permasalahan mitra dan merumuskan solusi melalui program pengabdian masyarakat. Seluruh tahapan kegiatan dilakukan dengan berkelompok. Anggota dasa wisma dibagi menjadi 4 kelompok berdasarkan RT. Selain itu, tim pelaksana pengabdian masyarakat memberikan motivasi kepada seluruh anggota dasa wisma seupaya program pengabdian berjalan dengan lancar.

B. Pelatihan pengolahan hasil pertanian, peternakan, dan perkebunan. Tim pengabdian melakukan pelatihan dan pendampingan pengolahan makanan yang bekerjasama dengan LPK Kayu Manis. LPK Kayu Manis memberikan pengetahuan, cara kerja, dan pendampingan selama pelatihan pengolahan makanan. Setiap sesi pelatihan membutuhkan waktu 5 jam, mulai dari teori, praktik, dan evaluasi. Pelatihan pengolahan makanan dilakukan 4 kali dengan 4 variasi, yaitu brownies, nugget ayam, ayam kremes, dan jamur krispi.

C. Pelatihan pengemasan produk. Pelatihan pengemasan produk didampingi oleh Anton Sudarto. Peserta dikenalkan dengan berbagai model kemasan dan teknik pengemasan beserta branding. Selain itu, strategi pemasaran dan penjualan produk dilakukan dengan pemasaran sosial (social marketing) dan digital marketing. Pemasaran lebih didominasi menggunakan whatsapp.

D. Pendampingan Pengelolaan Keuangan. Tim pengabdian melakukan pendampingan terkait pengelolaan keuangan. Pendampingam yang dilakukan dengan cara sederhana karena mitra masih dalam tahap pemula melakukan usaha.

E. Monitoring dan evaluasi kegiatan pengabdian. Tim pengabdian melakukan monitoring setalah kegiatan pengabdian selesai. Monitoring bertujuan untuk memastikan bahwa pengabdian masyrakat sesuai rencana dan mampu memberikan solusi atas permasalahan mitra. Tim pengabdian juga memberikan beberapa bantuan alat untuk mendukung wirausaha mitra. Evaluasi dilakukan dengan sistematis untuk mengetahui kelebihan, kelemahanm dan program tindak lanjut kegiatan pengabdian. Kegiatan pengabdian ini diselenggarakan pada Bulan Juli - September 2020.

\section{HASIL DAN PEMBAHASAN}

Kegiatan pengabdian masyarakat dilaksanakan pada Dasa Wisma di Nasri Sumbersari Moyudan Sleman. Kegiatan diawalai dengan observasi dan pemecahan masalah ibu-ibu anggota dasa wisma. Jumlah anggota mitra yang terlibat dalam kegiatan ini sejumlah 11 orang. Setiap RT diwakili oleh 2-3 orang. Sebagian besar pendidikan anggota mitra lulusan SMA/SMK/ 
SMEA $(90,91 \%)$ dan sebagai ibu rumah tangga $(90,91 \%)$. Selain itu, 90,91\% anggota mitra memiliki penghasilan keluarga sebesar Rp 1.000.000 - Rp 2.000.000 dengan rata-rata anggota keluarga 3 orang. Berdasarkan observasi yang dilakukan, hanya 9,09\% anggota mitra yang pernah mendapatkan pelatihan kewirausahaan dan memiliki usaha. Anggota mitra memiliki usaha makanan (snack) setelah kegiatan pengabdian selesai $(81,82 \%$ ) dan $18,18 \%$ ingin berwirausaha dalam bidang lainnya. Tabel dibawah ini menyajikan profil anggota mitra

Tabel 1: Profil Anggota Mitra

\begin{tabular}{lllr}
\hline No & & Kriteria & Jumlah \\
\hline 1 & Jumlah anggota mitra & SMA/SMK/SMEA & 11 \\
2 & Pendidikan & SMP & $90,91 \%$ \\
& & Islam & $9,09 \%$ \\
3 & Agama & Ibu Rumah Tangga & $100 \%$ \\
4 & Pekerjaan & Asisten Rumah Tangga & $90,91 \%$ \\
& & Dibawah 1 juta & $9,09 \%$ \\
5 & Penghasilan Keluarga & Antara Rp 1.000.000- Rp 2.000.000 & $9,09 \%$ \\
& & & $90,91 \%$ \\
6 & Rata-Rata Jumlah Keluarga & & 3 \\
7 & Anggota mitra yang memiliki usaha & & $9,09 \%$ \\
8 & Anggota mitra yang pernah mendapatkan pelatihan & & $9,09 \%$ \\
& kewirausahaan & Makanan (snack) & $81,82 \%$ \\
9 & Rencana usaha yang diminati & Lainnya & $18,18 \%$ \\
\hline
\end{tabular}

Letak geografis mitra yang berada di dekat kantor kelurahan, berbagai jenjang sekolah seperti Pendidikan Usia Dini (PAUD), Sekolah Dasar (SD), Sekolah Menengah Pertama (SMP), pasar, berbagai pertokoan, pabrik, dan jalan utama yang menghubungkan antar desa dan kecamatan menjadi potensi untuk memasarkan berbagai olahanan makanan. Oleh karena itu, pengabdian ini memberikan pelatihan dan pendampingan pengolahan makanan. Kegiatan pertama yaitu observasi. Mitra dan tim peneliti diskusi mengenai program-program kegiatan. Kegiatan ini juga mendiskusikan berbagai permasalahan mitra dan analisis potensi yang dimiliki.

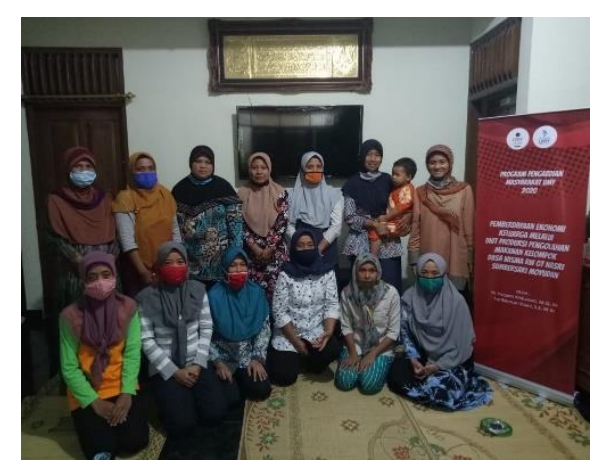

Gambar 5: Sosialisasi Program Pengabdian Masyarakat

Mitra dibekali dengan ketrampilan pengolahan makanan, yaitu brownies, nugget ayam, ayam kremes, dan jamur krispi. Pemilihan menu makanan olahan berdasarkan musyawarah tim usaha yang dibentuk dan paling diminati untuk mereka jalankan. Persaingan usaha brownies kukus tergolong ketat tetapi peluang bisnis ini masih cukup terbuka. Mitra berfokus pada rasa yang enak, tekstur yang empuk, kemasan sederhana, dan harga terjangkau untuk masyarakat di wilayah Sumbersari. Kegiatan ini fokus pada pengolahan nugget ayam. Ada beberapa alasan memilih pengolahan nugget. Pertama, pembuatan nugget relatif mudah untuk mitra yang sedang memulai usaha. Kedua, pembuatan nugget dapat menggunakan alat-alat sederhana yang sudah dimiliki mitra. Ketiga, ada berbagai variasi nugget, misalnya nugget ayam, sayuran, ikan dll. Kegiatan usaha pembuatan nugget mampu mendatangkan laba yang cukup tinggi. Selain itu, usaha ini relatif mudah dijalankan dan tidak membutuhkan modal besar serta peralatan khusus. 
Ayam kremes menjadi salah satu makanan favorit untuk anak-anak hingga orang tua. Olahan ayam goreng dengan tekstur yang renyah ini mampu menggugah selera masyarakat sehingga bisnis ini tetap diminati oleh banyak orang. Selain itu, usaha jamur crispy juga tidak kalah menjanjikan. Budidaya jamur tiram di lingkungan Moyudan berkembang pesat sehingga tersediannya bahan baku yang melimpah. Proses produksi jamur crispy sangat sederhana, mulai dari pencucian, pemotongan, penaburan adonan bumbu, dan penggorengan.
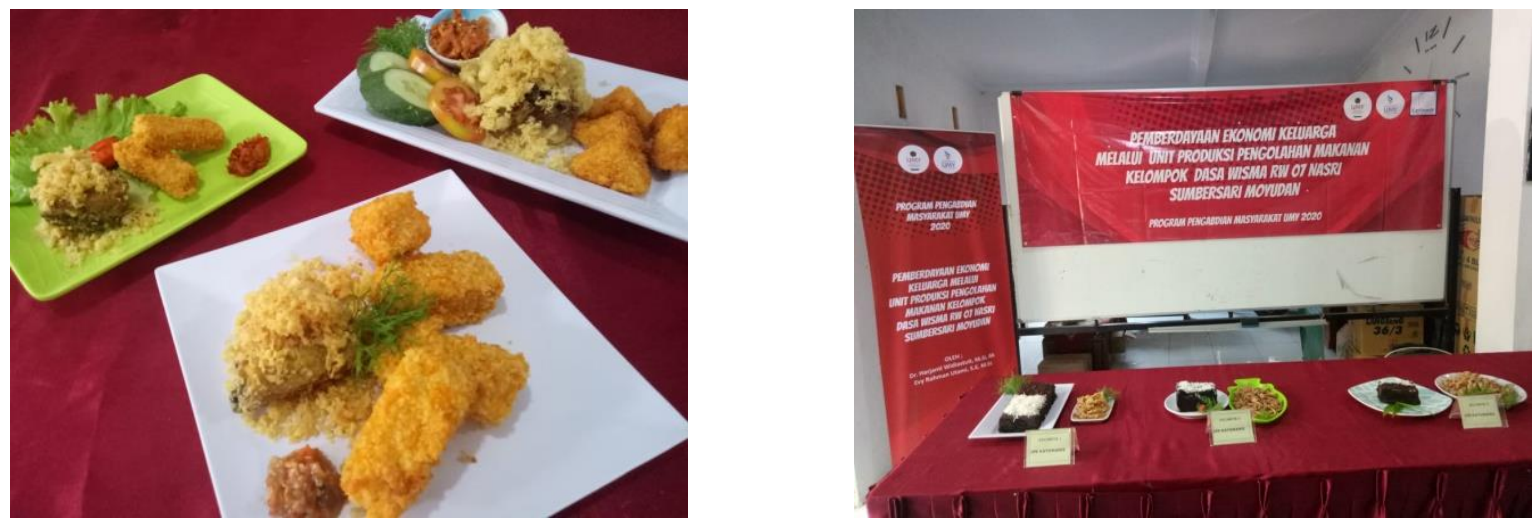

Gambar 6 dan 7: Hasil Olahan Mitra

Selain pengolahan makanan, mitra diberikan pelatihan pengemasan, pemasaran, dan pengelolaan keuangan. Tujuan pengemasan produk pangan yaitu kemasan harus menyediakan sifat-sifat perlindungan yang optimal untuk melindungi produk dari kerusakan dan mempertahankan nilai gizi (Sucipta, Suriasih, and Kenacana 2017). Pertimbangan lain bahwa pengemasan perlu didesain dengan bentuk dan ukuran yang sesuai serta desain grafis yang mampu menarik pembeli. Dalam jangka pendek, pemasaran dilakukan secara offline dan online dengan aplikasi whatsapp. Pemasaran offline dengan cara dijual ke warung atau toko disekitar Sumbersari serta dipasarkan pada berbagai kegiatan masyarakat (senam, pertemuan lansia, pertemuan PKK, dan arisan). Program pengabdian lainnya yaitu pendampingan pengelolaan keuangan. Pendampingan pengelolaan keuangan penting dilakukan untuk kelancaran operasional usaha (Layyinaturrobaniyah and Muizu 2017). Manajemen atas arus keluar masuk dana mampu mengontrol kegiatan usaha. Disisi lain, untuk mendukung perkembangan usaha mitra, tim pengabdi memberikan bantuan alat berupa mixer dan panic "kukus" kepada setiap anggota mitra.
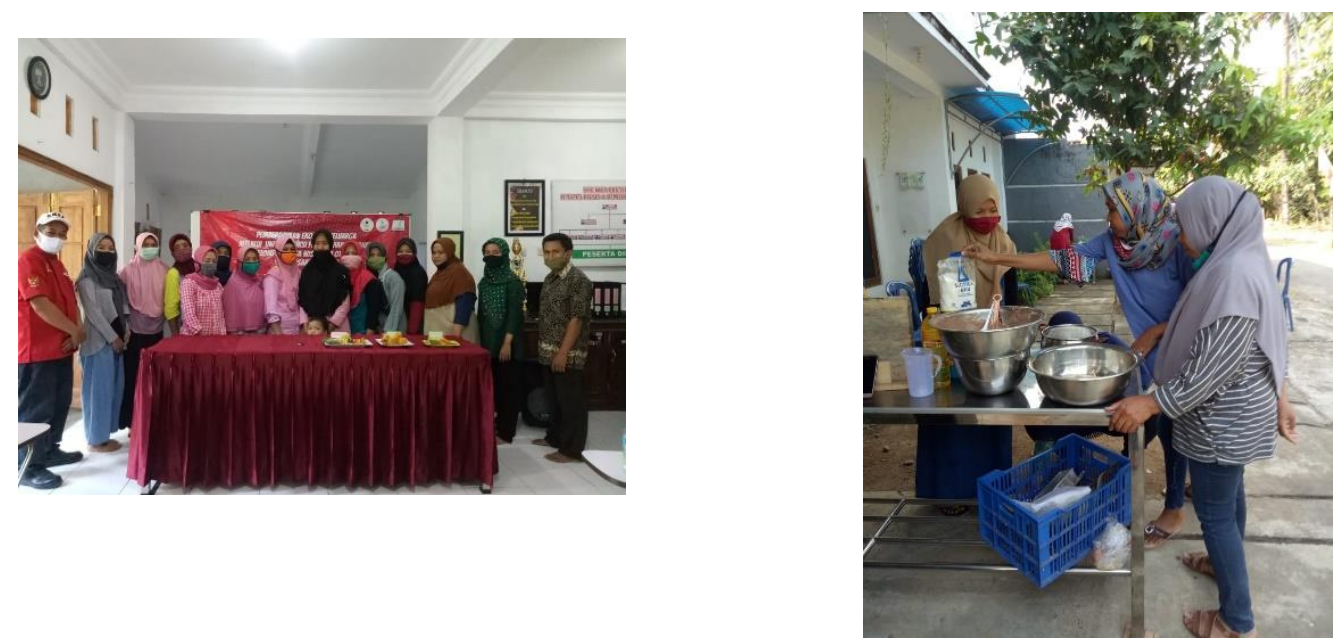

Gambar 8 dan 9: Praktik Pengolahan Makanan

Program pengabdian masyarakat ini mampu berperan dalam (1) penguatan ekonomi khususnya para perempuan kelompok dasa wisma, (2) pendampingan sebagai kelompok dasa 
wisma yang kreatif secara ekonomi, dan (3) pemberdayaan kaum perempuan dengan peningkatan ketrampilan pengolahan makanan untuk kemandirian ekonomi \& kesejahteraan masyarakat. Pemberdayaan masyarakat yang menitikberatkan peningkatan kemampuan masyarakat merupakan salah satu strategi untuk mengentaskan kemiskinan dan peningkatan ide kreatif di masyarakat. Salah satu upaya yang dilakukan dengan memfasilitasi kaum perempuan untuk melakukan aktiviatas bersama-sama dalam satu kelompok dasa wisma. Disisi lain, tantangan ekonomi di masa pandemi semakin berat untuk itu perlu semakin tingginya peran perempuan dalam ekonomi keluarga.

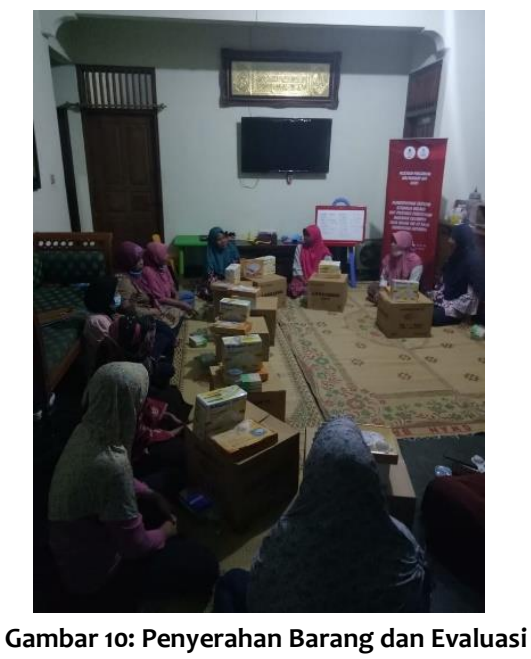

Berdasarkan evaluasi yang dilakukan, mitra pengabdian memberikan kesan yang baik, kegiatn pengabdian sesuai dengan rencana dan hasil kegiatan ini bermanfaat kepada mitra. Berikut evaluasi dari mitra:

Tabel 2: Evaluasi kegiatan Pengabdian

\begin{tabular}{|c|c|c|c|}
\hline No & Pertanyaan & Sangat Setuju & Setuju \\
\hline 1. & Jenis resep masakan yang diajarkan mudah untuk dipraktikan. & $63,64 \%$ & $36,36 \%$ \\
\hline 2. & Jenis resep masakan yang diajarkan sangat mungkin untuk dipasarkan. & $18,18 \%$ & $81,82 \%$ \\
\hline 3. & Bahan resep masakan yang disediakan sudah memadai. & $27,27 \%$ & $72,73 \%$ \\
\hline 4. & Peralatan memasak yang disediakan sudah memadai. & $36,36 \%$ & $63,64 \%$ \\
\hline 5. & Intruktur memasak hari pertama memandu dengan baik. & $27,27 \%$ & $72,73 \%$ \\
\hline 6. & Intruktur memasak hari kedua memandu dengan baik. & $9,09 \%$ & $90,91 \%$ \\
\hline 7. & $\begin{array}{l}\text { Materi "Literasi Keuangan Keluarga" bermanfaat untuk mengelola keuangan } \\
\text { rumah tangga. }\end{array}$ & $63,64 \%$ & $36,36 \%$ \\
\hline 8. & Pemateri "Literasi Keuangan Keluarga" menyampaikan materi dengan baik. & $9,09 \%$ & $90,91 \%$ \\
\hline 9. & $\begin{array}{l}\text { Peralatan memasak yang dihibahkan ke peserta akan bermanfaat untuk kegiatan } \\
\text { pengembangan ekonomi. }\end{array}$ & $54,55 \%$ & $45,45 \%$ \\
\hline 10 . & Secara keseluruhan, program dilaksanakan dengan baik. & $36,36 \%$ & $63,64 \%$ \\
\hline 11. & $\begin{array}{l}\text { Secara keseluruhan, program yang diberikan bermanfaat untuk pengembangan } \\
\text { ekonomi. }\end{array}$ & $45,45 \%$ & $54,55 \%$ \\
\hline
\end{tabular}

\section{KESIMPULAN}

Program pengabdian ini diharapkan memberikan solusi atas permasalahan ekonomi yang dialami mitra, terutama karena efek pandemik. Program ini didesain untuk meningkatkan kualitas sumberdaya manusia kelompok dasawisma tentang kewirausahaan, khususnya di bidang pengolahan makanan, dan manajemen keuangan. Peningkatan kualitas SDM diperoleh dalam bentuk peningkatan pengetahuan dan ketrampilan mitra melalui berbagai pelatihan yang diberikan. Pelatihan yang diberikan berupa pelatihan pengolahan makanan, pengemasan, pemasaran, dan manajemen keuangan. 


\section{SARAN}

Program pengabdian ini sudah terlaksana dengan baik, memberi manfaat, dan memberikan semangat ibu-ibu dasa wisma berwirausaha secara individual. Sedangkan usaha berbasis kelompok masih belum berjalan dengan baik, hanya berjalan saat ada event. Keberlanjutan program wirausaha kelompok pada dasawisma RW 07 perlu dipelihara dengan memberikan pelatihan motivasi usaha secara berkala, pelatihan pemasaran yang lebih advance (seperti pemasaran berbasis web), membangun akses pemasaran ke market place, dan pengurusan ijin usaha ke dinas perindustrian.

\section{UCAPAN TERIMA KASIH}

Penulis mengucapkan terima kasih kepada

1. Lembaga Penelitian, Publikasi, dan Pengabdian Masyarakat (LP3M) Universitas Muhammadiyah Yogyakarta atas dana yang disediakan untuk kegiatan pengabdian kepada masyarakat ini.

2. Masyarakat Nasri Sumbersari Moyudan Sleman

3. LPK Kayu Manis

4. Yudha Perwira Sahid Mahasiswa akuntansi UMY yang telah membantu pelaksanaan pengabdian

\section{DAFTAR PUSTAKA}

Layyinaturrobaniyah, and Wa Ode Zusnita Muizu. 2017. "Pendampingan Pengelolaan Keuangan Usaha Mikro Di Desa Purwodadi Barat Dan Pasirbungur Kabupaten Subang.” Pekbis Jurnal 9: 91-103.

Mukeri. 2012. "Kemandirian Ekonomi Solusi Untuk Kemanjuan Bangsa.” Majalah Ilmiah Universitas Pandanaran 10(24).

Sadli, S. 2015. "Lansia Moyudan Tetap Produktif Di Usia Senja." Pemerintah Kabupaten

Sleman. http://www.slemankab.go.id/6681/lansia-moyudan-tetap-produktif-di-usiasenja.slm.

Saugi, Wildan, and Sumarno Sumarno. 2015. "Pemberdayaan Perempuan Melalui Pelatihan Pengolahan Bahan Pangan Lokal." Jurnal Pendidikan dan Pemberdayaan Masyarakat 2(2): 226.

Sucipta, I Nyoman, Ketut Suriasih, and Pande K.D Kenacana. 2017. "Pengemasan Pangan Kajian Pengemasan Yang Aman, Nyaman, Efektif Dan Efisien." Udayana University Press: 1-178. http://penerbit.unud.ac.id. 